\author{
Muhammet Ruhat Yasar \\ Kilis 7 Aralik University, Turkey \\ Zeynel Amac \\ Kilis 7 Aralik University, Turkey
}

\title{
TEACHING SYRIAN STUDENTS IN TURKISH SCHOOLS: EXPERIENCES OF TEACHERS
}

Summary. The Syrian civil war affected Turkey so much that approximately three and a half million Syrians live in Turkey. Ministry of Education implemented an inclusive approach to schooling of Syrian asylum-seekers' children by educating them in public schools with their Turkish peers in the same classrooms in 2016 in order to address their educational needs, integration into the Turkish culture, and to prevent generation gap. Education, as a basic human right and as a way of integration into the Turkish society, is provided for free at all levels of education in Turkey. The inclusion of Syrian students in the Turkish school environment is quite a new experience for Turkish teachers and if the inclusion process is not managed properly, it may have negative effects on both students and their teachers. The purpose of this phenomenological study was to explore the experiences of teachers teaching Syrian students in the city of Kilis, where the number of asylum-seekers outnumbered the local population and almost one-fifth of the students in public schools are Syrians. The guiding question of this research was "What are the lived experiences of primary and middle school teachers educating Syrian children in culturally inclusive classrooms?" Five teachers from four different primary and middle schools were interviewed. The six open-ended interview questions allowed the participants to reflect on their experiences. The data were collected during the spring semester of 2017. The interviews were analyzed according to thematic methods. Three themes emerged: language barrier, lack of family support, and teachers' lack of pedagogical skills to teach asylum-seeker students.

Keywords: educating refugees; kilis; middle schools; multiculturalism; Syrians; primary schools.

\section{Introduction}

The Syrian conflict began in 2011 and affected Turkey so much that approximately three and a half million asylum-seekers now live in different cities of Turkey (Directorate General of Migration Management, 2018). According to AFAD Disaster and Emergency Management Presidency (2018), most of the Syrians live outside the camps. Until the 2016-2017 academic year, the Syrian students used to attend temporary education centers that only accept Syrian students and these schools were governed by Syrian expats with the guidance of the Ministry of Education. In these centers, most of the teachers were Syrians and according to Amac and Yasar (2017), the teachers 
in these centers lacked adequate pedagogical skills, and the conditions of the temporary education centers were not at the level needed to educate these Syrian students well.

To meet Syrian children's educational needs, integrate them into the Turkish culture, and to prevent generation gap (UNICEF, 2017), Ministry of Education in Turkey implemented an inclusive approach to the schooling of Syrian asylum-seekers' children by educating them in public schools with their Turkish peers in the same classrooms in 2016. At the beginning, the Syrian students were accepted into kindergarten, first, fifth, and ninth grades, based on their age. As a basic human right and as a way of integration into the Turkish society, education is provided to Syrians for free at all levels of education in Turkey.

Dryden-Peterson (2015) identifies three most common education experiences that refugee students face in countries of first asylum: "language barriers, teacher-centered pedagogy, and discrimination in school settings" (p. 1). Nofal (2017) reports that Syrian students arrived in Canada face problems related to reaching information, changes in family roles and language-related barriers in schools. Recent studies on asylum-seekers in Turkey concluded that Syrian students had PTSD (Ciğerci \& Güngör, 2016) and faced language barriers (Erdem, 2017).

The profile of Syrian students in Turkish schools includes the following (Adapted from Refugee Education Partnership Project, 2007):

$>$ Have had minimal schooling in Syria,

$>$ Have low levels or no skills in Turkish,

$>$ May have experienced some levels of violence before coming to Turkey,

$>$ Have PTSD,

$>$ Have lost at least a family member or a friend, and

$>$ May have disrupted schooling.

Research on teachers of Syrian students is limited. Only a handful of studies focused on teachers (eg. Yaylacı, Serpil, \& Yaylacı, 2017) of culturally inclusive classrooms. Because educating students from different backgrounds in terms of race, language, and culture is a novice issue for teachers, more needs to be learned about their experiences in culturally inclusive classrooms. The inclusion of Syrian students in Turkish school environment is quite a new experience for 
Turkish teachers, and if the inclusion process is not managed properly, it may have negative effects on both students and their teachers.

\section{Methodology}

Phenomenology is a qualitative research methodology that focuses on the lived experiences of individuals (Van Manen, 1990, 2014; Merriam \& Tisdell, 2016). According to Bhattacharya (2017), phenomenology "accounts for people's understanding of their lived experience of a phenomenon, focuses on lived experiences of a phenomenon, questions the meaning made of the phenomenon being experienced, and essence of the shared experiences of the phenomenon." (p. 64). The purpose of phenomenological studies is to explore "what a particular experience means for people who have experienced a shared phenomenon so that the structure of the experience can be understood and the essence of the experience can be abstracted" (Bhattacharya, 2017, p. 27). The purpose of choosing phenomenology as a research design was our intention to explore how a group of teachers make meaning of a shared phenomenon of "teaching Syrian students in Turkish schools." The purpose of this phenomenological study was to explore the experiences of teachers who are teaching Syrian students in the city of Kilis, where the number of asylumseekers outnumbered the number of the local residents and almost one-fifth of the students in public schools are Syrians.

The guiding question of this research was "What are the lived experiences of elementary and middle school teachers educating Syrian children in culturally inclusive classrooms?" We collect the data through indepth semi-structured interviews. Five teachers from four different primary and middle schools were interviewed. Table 1 shows detailed information about the participants. The participants were selected through snowball sampling, which is a type of purposive sampling (Merriam \& Tisdell, 2016). To be a part of the study, the teachers must have at least five or more Syrian students in their classrooms and have at least three years of teaching experience.

After the study was approved by the university and Ministry of Education, we started recruiting the participants. To do so, first, we introduced the purpose of the study and then asked for their participation. We told them 
that the participation was voluntary. The interviews were done in different public schools of Kilis, Turkey. The data were collected at the end of the spring semester of 2017.

We used six open-ended interview questions that allowed the participants to reflect on their culturally inclusive experiences. The interviews were audio recorded and transcribed verbatim. The interviews were analyzed according to thematic methods (Bryman, 2012). In the first phase, the researchers read the interviews and then listened to the audio recordings to see if something was missing, and to get a sense of the discussion. In the second phase, each researcher independently open coded the interviews that allowed to start from raw data and without "preestablished testable hypothesis" (Bhattacharya, 2017, p. 150). Then the codes were checked jointly. At the end of the coding process, the emerged themes were identified. For the purpose of credibility issues, the final themes were checked by a faculty member, who has years of experience in teaching and research. By doing this, we received feedback about the findings. We also asked participants to reflect on the themes. This was especially important in ensuring participant confirmation. To protect the identity of the participants, the teachers were coded as T1, T2, T3, T4, and T5.

During the interviews and data analysis, we tried as much as possible engaging in the bracketing or epoche (Moustakas, 1994) process in which we left behind our beliefs, biases, and values about teaching Syrian students in culturally inclusive classrooms in order to see and to understand the essence of the phenomenon that experienced by the participants. To do so, we wrote memos (Glaser, 1998) during the interviews and the analysis period so that we could eliminate our preconceptions about the phenomenon. It is important to note here that we have been living in a city that hosts more than one hundred Syrians for six years. They are now our neighbors, our friends, and our students. We believe that education is a basic human right and the kids of Syrian asylum-seekers should be taught in Turkish schools with their Turkish peers by Turkish teachers so that the integration process would be easier. 
Table 1.

The participants of the study

\begin{tabular}{ccllcc}
\hline $\begin{array}{c}\text { Participant } \\
\text { Code }\end{array}$ & Gender & School/Grade & Subject & $\begin{array}{c}\text { Years of } \\
\text { Teaching } \\
\text { Experien } \\
\text { ces }\end{array}$ & $\begin{array}{c}\text { The } \\
\text { Number } \\
\text { of Syrian } \\
\text { Students } \\
\text { in the } \\
\text { Class }\end{array}$ \\
\hline T1 & M & Primary/First & All subjects & 5 & 12 \\
T2 & F & Primary/First & All subjects & 6 & 10 \\
T3 & F & Primary/First & All subjects & 4 & 12 \\
T4 & F & Middle/Fifth & Social Studies & 5 & 9 \\
T5 & M & Middle/Fifth & Science & 4 & 10 \\
\hline
\end{tabular}

\section{Findings}

Three themes emerged from the analysis of the data: Language barrier, lack of family support, and teachers' lack of pedagogical skills to teach asylumseeker students. Figure 1 shows a summary of the findings of the study. According to this, "teachers' lack of pedagogical skills to teach Syrian students" theme can be linked with the lack of family support theme because Syrian families do not speak Turkish, creating a language barrier.

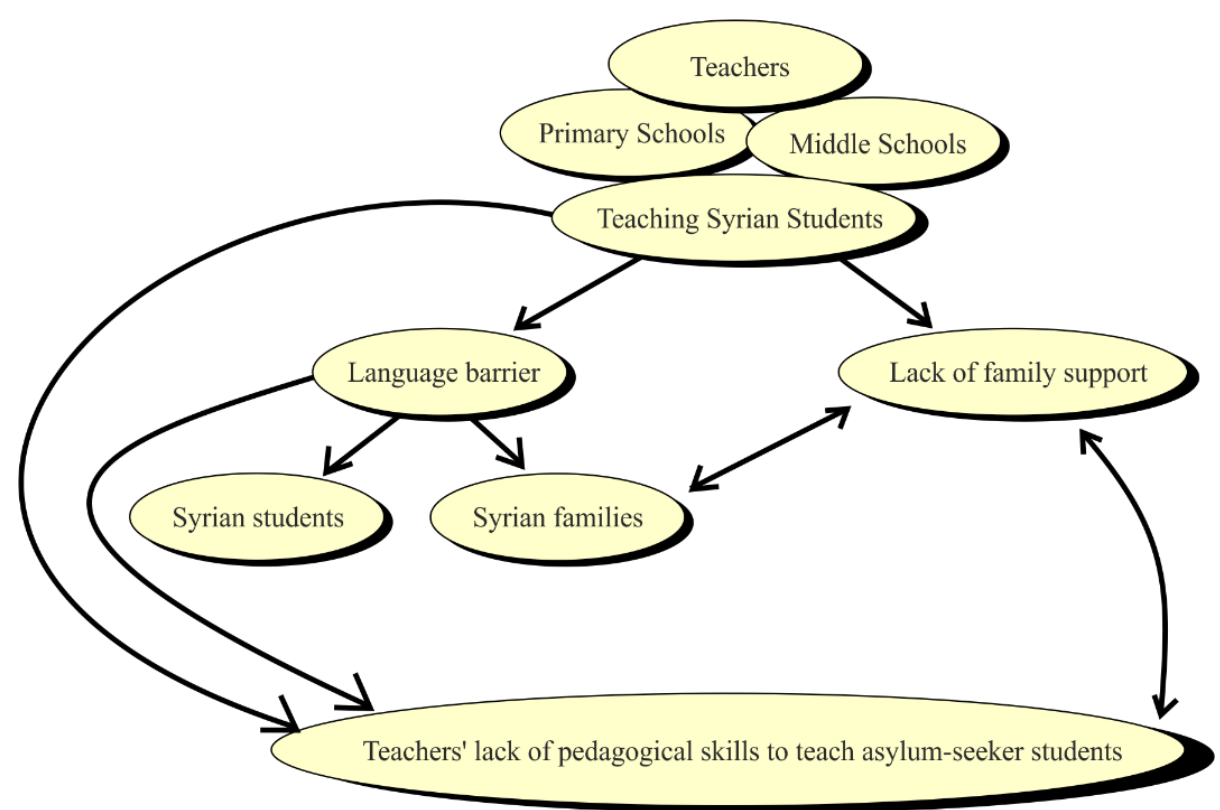

Fig. 1. Summary of the findings 


\section{Language Barrier}

Language is an important part of communication and, undoubtedly, education is based on communication. Because the Syrian students lack adequate Turkish language skills, the teachers experienced challenges during teaching. Here are some excerpts from the interviews:

"Because Syrians do not speak Turkish, they don't understand what I say. And this makes me sad." (T1, Male, Primary School Teacher)

"They don't speak Turkish. I experience difficulties with language. It is a big barrier." (T2, Female Primary School Teacher)

"Especially in social studies, they just stare at me because they don't understand what I am saying." (T3, Female, Primary School Teacher)

"They can't make themselves understood because of the language barrier." ( $T$, Female, Middle School Teacher)

"They are in trouble because they come without speaking Turkish. They can't even tell us the need for toilets." (T5, Male, Middle School Teacher)

\section{Lack of Family Support}

Family support is crucial in children's education. However, in the Syrian case, the teachers complain that the parents of their Syrian students do not support the students. Family support is crucial to children's education. However, in the Syrian case, the teachers complain that Syrian students' parents do not support the students. Because of the lack of family support, the education quality of the students is not at the desired level. The teachers stated their experiences with Syrian families as follows:

"When they first arrived in my class, there were students crying hungrily because they don't have breakfast at home. In the last three hours of the school, they were sleeping in their seats because they don't get enough sleep. When I tell the parents about this, they say OK, but then everything is same. Syrian parents don't support. Most of the parents don't come to teacher-parent meetings. Muhammad's mother never came, for example." (T2, Female, Primary School Teacher)

"At least half of the Turkish parents were interested in their children. I have six Syrian students, but I am not satisfied with 
any of them. Their parents don't even come to the school to speak with me about their children. When I ask why, they just say 'I have some other chores to do.' They are not interested in their children's education. Parents' support is important in education." (T3, Female, Primary School Teacher)

"They expect everything from the government. They say that their government [the Syrian regime] used to give everything. They did not have to spend a dime for the school. They don't support their kids." (T4, Female, Middle School Teacher)

"Syrian parents don't speak Turkish. They rarely came to teacher-parent meetings. I speak with them through a professional interpreter or a Turkmen student, who speaks both Turkish and Arabic. Because the parents don't support their children at home, there is no progress at all." (T5, Male, Middle School Teacher)

\section{Teachers' lack of pedagogical skills to teach asylum-seeker students}

Teachers are a crucial part of children's education because they design the teaching and learning environment. While teaching asylum-seeker students, their pedagogical skills are important because asylum-seeker students have unique conditions that must be understood, and their needs must be met. However, the teachers in this study report that they did not take any courses related to immigrant or asylum-seeker children's education during their preservice teacher education years. Although the Ministry of Education provided an in-service training workshop about Syrian students, they think that it was inadequate to educate Syrian students properly. Here are some quotes from the interviews about the issue:

"No, I don't do home visits." (T1, Male, Primary School Teacher)

"It is difficult to design an educational environment that half Turkish and half Syrian. I'm not prepared for this." (T2, Female, Primary School Teacher)

"We attended a seminar about Syrian students in December, but it wasn't enough. We just got some theoretical information. It must be more practical that I can use in the classroom. I feel powerless for teaching these Syrian kids." (T3, Female, Primary School Teacher). 


\section{Conclusions}

This study was conducted in a city in which one-fifth of the students in public schools are from Syrian background. We interviewed five teachers from primary and middle schools. Our analysis revealed that Turkish teachers who teach Syrian students in multi-cultural classrooms experienced language problems, lack of support from Syrian families, and lack of the prerequisite skills to meet Syrian students' educational needs.

Building a new life in a very different country brings challenges. Among others, this includes the language barrier, culture clash, and financial problems. These Syrian children registered in Turkish schools without getting any preparatory language courses, which means that the students from an Arab background (There are some students from Turkmen students, who can speak Turkish) did not speak any Turkish. Naturally, the teachers faced some students whose native language is different from their own. When they do not speak the same language, the clash is inevitable. The most important thing the teachers in this study face while teaching Syrian students is these students' lack of proper Turkish language skills. The teachers think that this causes a language barrier that prevents teachers from teaching and the students from learning. Tamer (2017) found similar results in her study that the teachers of Syrian students in the city of Trabzon experienced language problems with their students. According to Ciğerci and Güngör's (2016) study, Syrian students face difficulties such as "difficulty in comprehension, difficulty in making communication, and difficulty in self-expression" (p. 145) because of not having enough Turkish language skills. This theme is consistent with prior studies in the literature, both in Turkey and in other countries, where people seek asylum (Dooley, 2009; Dryden-Peterson, 2015; Erdem, 2017; Nofal, 2017; Sarıtaş, Şahin, \& Çatalbaş, 2016). Because these children will continue their education in culturally inclusive classrooms with their Turkish peers, the necessary language support should be provided. This can be, perhaps as a part of the after-school program. It is also important to note that creating opportunities for peer learning can help teach the Turkish language.

Family involvement is an important part of children's education (Ule, Živoder, \& du Bois-Reymond, 2015) and cooperation between parents and teachers can increase students' academic, social, and cultural achievement. 
This is especially important for refugee or asylum-seeker students (Jeynes, 2003; Kanu, 2008; Koyama \& Bakuza, 2017; Tang, 2012). According to a study by Rah, Choi, and Nguyen (2009), there are three important barriers to refugee parent involvement: "Language proficiency, time constraints due to family socioeconomic status and traditional family structures, and deferential attitudes towards school authority" (p. 352). The teachers in this study report that Syrian parents do not support their children in school settings. Because of the lack of family support, the teachers teaching Syrian kids face challenges. This also prevents Syrian kids to get a better education. We think that the lack of family support is linked to the language barrier that is also the case for the parents. Because the Syrian parents do not speak fluent Turkish, they can hesitate to contact teachers and school administrators. It is also important to note that the parents cannot help their children academically at home because of the language challenges. Consistent with this theme, Sarıtaş, Şahin, and Çatalbaş (2016) found in their study that the parents of Syrian students, according to the teachers, do not pay attention to their kids' education. The researchers indicate that this is because of financial problems and not knowing enough Turkish to communicate with the teachers and assist their kids with homework. The lack of family support theme in the present study is similar to the findings of Tamer's (2017) study that Syrian students do not get support at home because "nobody speaks Turkish at home" (p. 132). To increase family involvement in Syrian kids' education, the following can be suggested: a) Turkish language programs for families, b) Programs for increasing Syrian parents' cultural capital, c) Financial support, c) Social cohesion programs to bring Turkish and Syrian families together, d) Programs for informing asylumseekers' rights, and e) Home visits by the teachers.

Teachers in this study note that they do not have adequate pedagogical skills about teaching refugee or asylum-seeker students. They admit that they had difficulties while designing the learning environment and communicating with the students and their parents. The teachers of the study indicate that they did not receive any training about teaching Syrian students. They also indicate that their pre-service teacher education programs lacked courses related to students from refugee backgrounds. İmamoğlu and Çalışkan (2017) found in their study that the teachers of Syrian students were not supported and could not access information regarding refugee education. Similarly, Aydın 
and Kaya, (2017); Er and Bayındır, (2015); Taşkaya and Ersoy, (2016); and Tösten, Toprak, and Kayan, (2017) found that the teachers teaching Syrian students were not supported and were not prepared to teach refugee background students. Teaching students from different backgrounds and providing them with a safe and welcoming environment, specifically refugee or asylum-seeker students, require a lot of training and effort. For this reason, teachers of Syrian students should be supported. Based on this theme, it can be suggested that the teacher education for primary and middle school teachers in Turkey should be reformed, due to the fact that Syrian students will be a big part of the Turkish schools in the next decade. The courses related to the conditions of students from refugee backgrounds, addressing their unique educational needs, and designing teaching and learning environments for all learners should be a part of pre-service teacher education. In addition to this, in-service teachers should be offered programs related to refugee education. It is also important to note that there should be opportunities for teachers to learn from each other, and especially the teachers who are experienced in teaching Syrian students should be a part of such programs.

Finding a quick resolution to the Syrian conflict seems difficult in the near future and the Syrians will continue to be a part of the Turkish community. To educate their children and make the integration process easier, teachers should undertake bigger roles. We believe that learning more about Syrian children's multicultural experiences and designing the culturally responsive education they need based on these experiences is crucial.

Acknowledgments: This work was supported by the Scientific Research Project Coordination Unit of Kilis 7 Aralık University. Project number: 11451. Portions of this work were presented at the International Conference on New Horizons in Education (INTE2018) in 2018, Syrian asylum-seekers' children in Turkish schools: Inclusion experiences of teachers."

\section{References}

AFAD Disaster and Emergency Management Presidency. (2018). Turkey's response to Syria crisis. Retrieved from https://www.afad.gov.tr/en/2601/Turkey-Response-to-Syria-Crisis 
Amaç, Z., \& Yaşar, M. R. (2017, October). Temporary education centers for Syrian asylum-seekers: Opportunities and challenges. Paper presented at the International Symposium on the Middle East. Kilis, Turkey.

Aydın, H., \& Kaya, Y. (2017). The educational needs of and barriers faced by Syrian refugee students in Turkey: A qualitative case study. Intercultural Education, 28(5), 456-473. doi: 10.1080/14675986.2017.1336373.

Bhattacharya, K. (2017). Fundamentals of qualitative research: A practical guide. New York, NY: Routledge.

Bryman, A. (2012). Social research methods (4th ed.). New York, NY: Oxford University Press.

Ciğerci, F. M., \& Güngör, F. (2016). The problems encountered by the foreign primary school students from the perspective of classroom teachers. Journal of Education and Future, 10, 137-164.

Directorate General of Migration Management. (2018). Distribution by age and gender of registered Syrian refugees recorded by taking biometric data. Retrieved from http://www.goc.gov.tr/icerik3/gecicikoruma_363_378_4713.

Dooley, K. (2009). Rethinking pedagogy for middle school students with little, no or severely interrupted schooling. English Teaching Practice and Critique. 8(1), 5-22.

Dryden-Peterson, S. (2015). Refugee education in countries of first asylum: Breaking open the black box of pre-resettlement experiences. Theory and Research in Education, 14(2), 1-18.

Er, A. R., \& Bayındır, N. (2015). Pedagogical approaches of elementary teachers for primary refugee children. International Journal of Social and Educational Sciences, 2(4), 175-185.

Erdem, C. (2017). Sınıfında mülteci öğrenci bulunan sınıf öğretmenlerinin yaşadıkları öğretimsel sorunlar ve çözüme dair önerileri. Medeniyet Eğitim Araştırmaları Dergisi, 1(1), 26-42.

Glaser, B. G. (1998). Doing grounded theory: Issues and discussions. Mill Valley, CA: Sociology Press.

İmamoğlu, H. V., \& Çalışkan, E. (2017). Yabancı uyruklu öğrencilerin devlet okullarında ilkokul eğitimine dair öğretmen görüşleri: Sinop ili örneği. Karabük Üniversitesi Sosyal Bilimler Enstitüsü Dergisi, 7(2), 529-546. 
Jeynes, W. H. (2003). A meta-analysis: The effects of parental involvement on minority children's academic achievement. Education and Urban Society, 35(2), 202-218. doi:10.1177/0013124502239392.

Kanu, Y. (2008). Educational Needs and Barriers for African Refugee Students in Manitoba. Canadian Journal of Education. 31 (4), 915-940.

Koyama, J., \& Bakuza, F. R. (2017). A timely opportunity for change: Increasing refugee parental involvement in U.S. schools. Journal of Educational Change, 18(3), 311-335. doi: 10.1007/s10833-017-92997.

Merriam, S. B. \& Tisdell, E. J. (2016). Qualitative research: A guide to design and implementation (4th ed.). San Francisco, CA: Jossey.

Moustakas, C. (1994). Phenomenological research methods. Thousand Oaks, CA: SAGE.

Nofal, M. (2017). For our children: A research study on Syrian refugees' schooling experiences in Ottawa. Master's Thesis. University of Ottawa, Faculty of Graduate and Postdoctoral Studies. Ottawa, ON: Canada.

Rah, Y., Choi, S., \& Nguyen, T. S. T. (2009). Building bridges between refugee parents and schools. International Journal of Leadership in Education, 12(4), 347-365.

Refugee Education Partnership Project (2007). The Education Needs of Young Refugees in Victoria. Retrieved from http://www.cmy.net.au/sites/default/files/publicationdocuments/Education\%20Needs\%20of\%20Young\%20Refugees\%20in \%20Vic\%202006.pdf.

Sarıtaş, E., Şahin, Ü., \& Çatalbaş, G. (2016). İlkokullarda yabancı uyruklu öğrencilerle karşılaşılan sorunlar. Pamukkale Üniversitesi Sosyal Bilimler Enstitüsü Dergisi, 25(1), 208-229.

Tamer, M. G. (2017). Geçici koruma kapsamındaki Suriyeli çocukların Trabzon devlet okullarındaki durumu. Göç Dergisi, 4(1), 119-152.

Tang, S. (2012). Family educational involvement and social capital: Potential pathways to educational success for students of immigrant families. Boston College, Chestnut Hill, MA.

Taşkaya, S. M., \& Ersoy, G. (2016). Suriyeli sığınmacılara Türkçe öğretiminde sınıf öğretmenlerinin uygulamaları. Çukurova Araştırmaları Dergisi, 2(1), 130-138. 
Tösten, R., Toprak, M., \& Kayan, M. S. (2017). An investigation of forcibly migrated Syrian refugee students at Turkish public schools. Universal Journal of Educational Research, 5(7), 1149-1160.

Ule, M., Živoder, A., \& du Bois-Reymond, M. (2015). 'Simply the best for my children': Patterns of parental involvement in education. International Journal of Qualitative Studies in Education, 28, 329-348.

UNICEF. (2017). Over 40 per cent of Syrian refugee children in Turkey missing out on education. Retrieved from https://www.unicef.org/media/media_94417.html.

van Manen, M. (1990). Researching lived experience: Human science for an action sensitive pedagogy. Ontario, Canada: The Althouse Press.

van Manen, M. (2014). Phenomenology of practice: Meaning-giving methods in phenomenological research and writing. Walnut Creek, CA: Left Coast Press.

Yaylacı, F. G., Serpil, H., \& Yaylacı, A. F. (2017). Paydaşların gözünden mülteci ve sığınmacılarda eğitim: Eskişehir örneği. Akdeniz Eğitim Araştırmaları Dergisi, 22, 101-117. 


\section{Muhammet Ruhat Yasar}

Kilis 7 Aralik universitetas, Turkija; ruhat@kilis.edu.tr

\section{Zeynel Amac}

Kilis 7 Aralik universitetas, Turkija; amacz12@gmail.com

\section{SIRIJOS VAIKY MOKYMAS TURKIJOS MOKYKLOSE: MOKYTOJU PATIRTYS}

Santrauka. Sirijos pilietinis karas taip pat paveikè ir Turkija, nes maždaug trys su puse milijono siru dabar gyvena šioje šalyje. Švietimo ministerija vykdo visapusišką Sirijos piliečiu, prašančiu prieglobsčio, vaiku mokymo programa, kurios pagrindinis tikslas yra vaiku mokymas valstybinėse mokyklose kartu su turku bendraamžiais. Ši programa pradèta vykdyti nuo $2016 \mathrm{~m}$. Taip siekiama užtikrinti siru vaiku švietimo poreikiu igyvendinima, integracija i turku kultūrą ir užkirsti kelia kartu atotrūkiui. Švietimas, kaip pagrindinè žmogaus teisè ir būdas integruotis i turku visuomenę, yra nemokamas visose Turkijos švietimo istaigose. Sirijos mokiniu integracija i turku mokyklas yra naujas iššūkis mokytojams, ir jei šis procesas nèra tinkamai vykdomas, tai gali turèti neigiamu pasekmiu tiek mokiniams, tiek ju mokytojams. Šio fenomenologinio tyrimo tikslas yra analizuoti mokytoju patirti mokant mokinius iš Sirijos, prisiglaudusius Kilio mieste, kuriame prieglobsčio prašančiu piliečiu skaičius viršijo vietos gyventoju skaičiu, ir beveik penktadalis mokiniu valstybinèse mokyklose yra sirai. Pagrindinis tyrimo klausimas kokios yra asmeninès pradiniu ir viduriniu mokyklu mokytoju, kurie moko vaikus iš Sirijos, patirtys. Apklausoje dalyvavo penki mokytojai iš keturiu skirtingu pradiniu ir viduriniu mokyklu. Šeši atviri interviu klausimai leido dalyviams apmastyti savo patirti. Duomenys buvo surinkti $2017 \mathrm{~m}$. pavasario semestro metu. Interviu buvo analizuojami naudojant temini metoda. Tyrime atskleistos trys pagrindinès problemos: kalbos barjeras, nepakankama šeimos parama ir pedagoginiu igūdžiu dirbant su prieglobsčio prašančiais mokiniais trūkumas.

Pagrindinès sąvokos: pabègèliu ugdymas; Kilis; pradinès mokyklos; vidurinès mokyklos; daugiakultūriškumas; sirai. 